\title{
The length of mucin MUC1 extracellular domain affects integrin- mediated cell adhesion to fibronectin and vitronectin
}

\author{
M. S. Syrkina ${ }^{1,2, *}$, DM. Potashnikova ${ }^{1}$, MA. Rubtsov ${ }^{1,2,3}$ \\ ${ }^{1}$ M. V. Lomonosov Moscow State University \\ Leninskie Gory, 1/12, Moscow, Russian Federation, 119991 \\ ${ }^{2}$ LIA LFR20 French-Russian Joint Cancer Research Laboratory \\ Villejuif, France-Moscow, Russian Federation \\ ${ }^{3}$ I. M. Sechenov First Moscow State Medical University, \\ 8, Trubetskaya Str. Moscow, Russian Federation, 119991 \\ krimsy@yandex.ru
}

\begin{abstract}
Aim. To determine whether the adhesion capacity of extracellular matrix proteins differs in cells stably expressing a recombinant fusion proteins containing different number of tandem repeats from the extracellular region of the human mucin MUC1. Methods. Cell adhesion assay, FACS analysis, confocal fluorescence microscopy. Results. With an increase in the number of tandem repeats in the extracellular region of MUC1, the uniform distribution of the protein in the region of contact with glass first changes to discrete, and then compact clusters are formed. Cell adhesion to vitronectin and fibronectin does not depend on the presence of integrin receptors on the cell surface and decreases in the following order: HT-29_TR4 $\rightarrow$ HT-29_TR12. For HT-29_TR20 cells, an increase in adhesion to these extracellular matrix proteins is observed. Integrins avb3 (vitronectin receptors) form clusters in all the cell lines analyzed, but integrins a5b1 (fibronectin receptors) form compact clusters only on the surface of HT-29_TR20 cells. Both integrins appear in the areas devoid of recombinant MUC1 molecules on the surface of HT-29_TR4, HT-29_TR12 and HT-29_TR20 cells and their distribution on the surface of HT-29_TR- cells does not depend on the recombinant protein localization. Conclusions. An increase in the number of repeats in the extracellular region of MUC1 from 12 to 20 leads to a noticeable decrease in the antagonism of mucin MUC1 with the integrin avb3 in the cell adhesion to vitronectin and an appearance a synergism with the integrin a5b1 in the cell adhesion to fibronectin
\end{abstract}

Ke y w o r d s: MUC1, integrin, avb3, a5b1, adhesion, clustering

\section{Introduction}

Hematogenous metastasis involves several key stages. It begins with the invasion of tumor cells from the primary tumor into the blood vessel [1]. Then circulating tumor cells (CTC)

(C) 2019 MS. Syrkina et al.; Published by the Institute of Molecular Biology and Genetics, NAS of Ukraine on behalf of Biopolymers and Cell. This is an Open Access article distributed under the terms of the Creative Commons Attribution License (http://creativecommons.org/licenses/by/4.0/), which permits unrestricted reuse, distribution, and reproduction in any medium, provided the original work is properly cited 
are brought by blood to various tissues and organs. On the latter stages, CTC attach to the endothelium of the blood vessels, which leads to extravasation and the formation of secondary tumor sites with an active participation of cell adhesion molecules at each stage. Thus, before an invasion an interaction occurs between the metastatic cells and the extracellular matrix molecules occurs, accompanied by proteolysis of matrix proteins and the movement of the tumor cell towards the blood vessels [2]. Attachment of a tumor cell to the vascular endothelium begins with an interaction between selectins on the surface of the endothelium cells and carbohydrate epitopes, such as sialyl Lewis $\mathrm{x}$ (sLex) or sialyl Lewis a (sLea), on the surface of CTC [3-7]. This process is followed by the formation of strong associations between the intercellular adhesion molecule 1 (ICAM-1) located on the surface of the endothelium and integrin receptors, presented by circulating cells. Extravasation implies interaction with matrix proteins and the motion of a metastatic cell from the vessel to adjacent tissues.

Integrin receptors play a key role in metastasis. Indeed, overexpression of integrin receptors correlates with a high metastatic potential [8]. Integrin-mediated interactions with extracellular matrix proteins occur at virtually every stage of metastasis, changing the mobility, shape and polarity of tumor cells [9] and, as a result, altering cell adhesion and migration capacity.

Mucin MUC1 may also be involved in the formation of intercellular associations and interaction of tumor cells with extracellular matrix proteins. MUC1 is a transmembrane glycoprotein, which is normally distributed on the apical surface of epithelial cells in glandular ducts and overexpressed in different can- cers. A large highly glycosylated extracellular domain of MUC1 forms a rod-like structure [10]. Its major part, a tandem repeat region, consists of repeated sequences of 20 amino acid residues and constitutes up to $50-80 \%$ of the entire protein molecule. The size of this region is variable and, as a rule, consists of 20-120 repeats [11, 12]. Moreover, some isoforms of MUC1 are devoid of the tandem repeat region $[13,14]$. Polymorphism of the tandem repeat region suggests that it may play a role in a cancer susceptibility or reflect the stage of the disease. Indeed, the isoforms lacking the tandem repeat region were found only in the tumor cells [15], although no clear correlations were identified between the tandem repeat number and cell malignization $[16,17]$.

Since MUC1 normally lubricates the epithelium of the glandular ducts, preventing adhesion of pathogenic microorganisms [18], it was logical to assume that in tumor cells, this molecule affects cell aggregation, leading to an increase in the cell ability to metastasize. For a long period of time, MUC1 was considered to be an antiadhesive molecule capable of disrupting intercellular interactions [19-21] and cell adhesion to extracellular matrix proteins [17]. However, in recent years more and more works have appeared indicating that the mucin MUC1 might enhance the cell adhesion capacity [22-26].

In addition to the ability of interaction with ICAM-1 molecules on the surface of vascular endothelium cells [25], the large tumor-associated glycoproteins (such as MUC1) were found to participate in integrin-mediated cell adhesion. Early works showed that cell adhesion to extracellular matrix proteins increased in response to clustering of MUC1 molecules on the cell surface [17], but the mechanism of the MUC1- 
medated adhesion was not described. On the contrary, the authors concluded that MUC1 disrupted cell adhesion, hiding integrin receptors, but MUC1 clustering led to demasking of integrin receptors giving them an opportunity to interact with ECM molecules. Many years later, it was discovered that bulk surface glycoproteins (such as MUC1) facilitated the clustering of integrin receptors thus leading to mechanical activation of integrins and an increase in the cell adhesion [27]. Using synthetic analogs of mucin MUC1, it was demonstrated that the size of the extracellular domain was essential for a cell adhesion. In case of using polymers extended from the cytoplasmic membrane by $80 \mathrm{~nm}$ (40 tandem repeats), the cell surface was "divided" into areas containing glycocalyx proteins and adhesion sites containing integrin receptors. Such separation was absent in case of using the polymers with a length of $3 \mathrm{~nm}$. Thus, with an increase in the size of the extracellular domain, the mucin MUC1 acquired the ability to modify the cell surface and "separate" it into the functional areas. At the same time, it is not entirely clear which size of the extracellular domain of the mucin MUC1 is sufficient for this molecule to facilitate integrin-mediated adhesion. To answer this question, we used HT-29 cell lines stably expressing recombinant proteins containing a different number of tandem repeats from the VNTR region of the human mucin MUC1 in their extracellular regions [28].

\section{Materials and Methods}

\section{Reagents}

Monoclonal and polyclonal antibodies were obtained from the following sources: anti-integrin $\alpha 5 \beta 1$, anti-integrin $\alpha v \beta 3$ antibodies,
Alexa647-conjugated goat anti-mouse immunoglobulin were purchased from Abcam (USA). All other chemicals and salts were purchased from Merck (Germany) and Amresco (USA). Tripan Blue solution was purchased from Thermo Fisher Scientific (USA).

Cell culture was performed using a Dulbecco's modified Eagle's medium (DMEM), Versen solution and trypsin solution (PanEco, Russian Federation); fetal calf serum (FCS) (Hyclone, USA); geneticin (G418), penicillin and streptomycin antibiotics were purchased from Sigma-Aldrich (USA).

Human vitronectin and fibronectin were purchased from Advanced Bio Matrix (USA).

\section{Cell Culture}

HT-29 cells (HT-29_TR-, HT-29_TR1, HT29_TR4, HT-29_TR8, HT-29_TR12 and HT29_TR20) expressing proteins with a different number of tandem repeats $(0,1,4,8,12$ and 20 , respectively) [28] were maintained in DMEM supplemented with $10 \%$ heat-inactivated fetal bovine serum, penicillin/streptomycin and $700 \mathrm{mg} / \mathrm{ml} \mathrm{G} 418$ in a humidified incubator at $37^{\circ} \mathrm{C}$ and $5 \% \mathrm{CO}_{2}$.

\section{Fluorescence microscopy}

The cells with $70 \%$ confluence grown on $35 \mathrm{~mm}$ plastic dishes, were washed with DPBS and incubated with Versen (10-15 minutes in a humidified incubator at $37{ }^{\circ} \mathrm{C}$ and $5 \% \mathrm{CO}_{2}$ ). Then Versen was aspirated and cells were detached with a stream of complete DMEM $(2 \mathrm{ml}) .400 \mu \mathrm{l}$ of cell suspension were put on the glass bottom of $35-\mathrm{mm}$ plates. EGFP fluorescence in live cells was analyzed after 24$48 \mathrm{~h}$ using an Eclipse Ts100 conformal fluorescent microscope (Nikon, Japan). 
For studing the colocalisation $200 \mu$ of cell suspension (cells were detached with Versen) put in the center of the washed and sterilized glass coverslips and incubated $24-48 \mathrm{~h}$ in a humidified incubator at $37^{\circ} \mathrm{C}$ and $5 \% \mathrm{CO}_{2}$. Then growth medium was removed, cells were washed gently with DPBS and fixed with $4 \%$ PFA in PBS for 10 minutes at room temperature. After gently washing 3 times with PBS, cells were incubated with a blocking solution ( $3 \%$ BSA in PBS) for 40 minutes at room temperature. Then cells were incubated with the primary anti-integrin a5b1 (dilution 1:1000) or anti-integrin avb3 antibodies (dilution $1: 500$ ) for $1 \mathrm{~h}$ at room temperature, washed three times with the blocking solution and incubated with Alexa647-labeled secondary antibodies (dilution 1:2000) for one hour at $37{ }^{\circ} \mathrm{C}$. Then cells were washed three times with PBS and coverslips were mounted on the microscope slides with the mounting medium.

\section{Cell adhesion assay}

One day before the assay, the ECM proteins (human fibronectin and vitronectin) were diluted with cold RPMI (final concentration of each protein was $20 \mu \mathrm{g} / \mathrm{ml}$ ) and $60 \mu \mathrm{l}$ of protein solution were placed into each well of a 96-well plate. The procedure was performed on ice to avoid ECM protein polymerization. The plate was incubated $1-2 \mathrm{~h}$ at $37^{\circ} \mathrm{C}$, and then the wells were washed 3 times by DPBS. $100 \mu 1$ of $2 \%$ BSA were placed into each well and the plate was incubated $1 \mathrm{~h}$ at $37^{\circ} \mathrm{C}$. Then solution was aspirated and the wells were washed 3 times by DPBS.

HT-29 cells were detached with Versen, counted using Tripan Blue and diluted with the complete DMEM to the final concentration of
$8,5 \times 10^{4}$ cells $/ \mathrm{ml} .100 \mu 1$ of cell suspension was placed in each well of the 96-well plate and incubated $2 \mathrm{~h}$ at $37^{\circ} \mathrm{C}, 5 \% \mathrm{CO}_{2}$. The specified time interval was determined for the selected lines experimentally as a result of preliminary experiments (data not shown). Increased incubation time led to the disapperance of the difference in the adhesion ability between different cell lines. Then growth medium with nonbound cells was removed and wells were gently washed twice with DPBS. $100 \mu 1$ of DMEM and $50 \mu 1$ of MTT solution (concentration $1.35 \mathrm{mg} / \mathrm{ml}$ ) were added to each well. Plates were incubated for $1.5 \mathrm{~h}$ at $37^{\circ} \mathrm{C}, 5 \% \mathrm{CO}_{2}$. The solution was removed and $200 \mu \mathrm{l}$ of DMSO was added in each well. The absorbance of samples were recorded at $570 \mathrm{~nm}$ with the NanoQuant Infinite M200 Pro plate reader (Tecan, Switzerland). Each assay was performed in triplicate and repeated at least three times.

The number of the attached cells was determined using the calibration curves plotted for each cell line. For calibration curves plotting cells were detached and counted as described above. 500, 1000, 2000 and 3600 cells suspended in the complete DMEM, were placed into the 96-well culture plate (each in triplicate) and incubated for $14 \mathrm{~h}$ at $37{ }^{\circ} \mathrm{C}$ in $5 \% \mathrm{CO}_{2}$. Then the growth medium was removed and the wells were gently washed twice with DPBS. MTT solution was added and after $1.5 \mathrm{~h}$ it was replaced by DMSO as described above. The absorbance of samples were recorded at $570 \mathrm{~nm}$.

\section{Analysis of integrin receptor expression}

Cells grown in $100 \mathrm{~mm}$ tissue culture plates to $70-90 \%$ confluence were detached with 
Versen, diluted with DPBS to a concentration of $1 \times 10^{6}$ cells $/ \mathrm{ml} .1 \mathrm{ml}$ of cell suspension was centrifuged ( $3 \mathrm{~min}$ at $1000 \mathrm{~g}$ ), DPBS was aspirated and the cells were resuspended in the mixture of primary anti-integrin a5b1 (dilution 1:500) or anti-integrin avb3 (dilution 1:500) and Alexa647-labeled secondary antibodies (dilution $1: 1000$ ) for $1 \mathrm{~h}$ at $4{ }^{\circ} \mathrm{C}$. Then cells were washed 3 times with DPBS and kept at $4{ }^{\circ} \mathrm{C}$ until analyzed by flow cytometry (BD FACS AriaIII, USA). Control cells were incubated with the secondary antibody only (dilution 1:2000).

\section{Statistical analysis}

For the EGFP fluorescence evaluation, the images of cells were divided into squares of $100 \mu \mathrm{m}^{2}$. The number of clusters was counted in each square. Data are represented as mean \pm SD. At least 10 areas were analyzed for each cell line.

\section{Results and Discussion}

Cell adhesion to vitronectin and fibronectin decreases with an increase in the number of tandem repeats up to 12. Addition of 8 supplementary repeats leads to a change in the cell adhesion profile

An ability of stably transfected cell lines expressing recombinant proteins to adhere to vitronectin and fibronectin was studied. The extracellular domains of these proteins (TR-, TR1, TR4, TR8, TR12 and TR20) are composed of different numbers of tandem repeats from the VNTR region of human mucin MUC1 $(0,1,4,8,12$ and 20 , respectively). These proteins also contain MUC1 transmembrane domain and anchoring fragment (Cys-Gln-
Cys). EGFP is located in the C-terminus [28]. The difference in the length of the recombinant proteins was confirmed by immunoblotting. [28].

In stably transfected HT-29 cells, the ability to adhere to vitronectin decreases in the following order: HT-29_TR1 $\rightarrow$ HT-29_TR4 $\rightarrow$ HT-29_TR8 $\rightarrow$ HT-29_TR12 (Fig. 1). An addition of 8 tandem repeats to TR12 leads to an unexpected increase in the cell adhesion to the extracellular matrix proteins. In the case of fibronectin, only HT-29_TR20 cells demonstrated increased adhesion ability in contrast with an extremely low adhesion in other cells.

This marked difference in the adhesion of HT-29_TR20 cells may be due to different expression levels of integrin receptors mediating the interaction with extracellular matrix proteins. To test this hypothesis, we determined the content of $\alpha 5 \beta 1$ and $\alpha v \beta 3$ integrins on the surface of HT-29_TR-, HT-29_TR4, HT-29_TR12 and HT-29_TR20 cells.

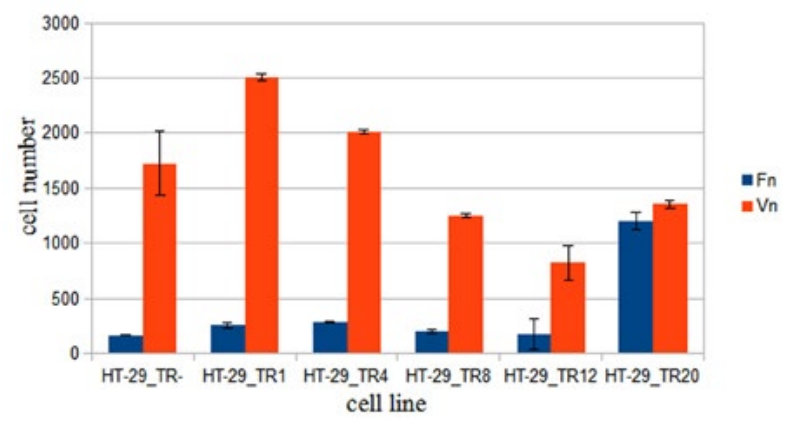

Fig. 1. Adhesion of stable cell lines expressing recombinant proteins with different numbers of tandem repeats in the extracellular region of MUC1 to fibronectin and vitronectin from fibroblasts. Data are expressed as mean cell number \pm SD. Each assay was performed in triplicate and repeated at least three times. 
The content of fibronectin- and vitronectin-binding integrin receptors on the surface of the stably transfected cells does not correlate with their adhesion capacity

Comparison of the amount of $\alpha 5 \beta 1$ and $\alpha v \beta 3$ integrin receptors on the surface of the HT29 TR-, HT-29_TR4, HT-29_TR12 and HT29 TR2 0 cells was performed by measuring the median of fluorescence intensity using FACS analysis with fluorescently labeled antibodies to different chains of integrin receptors.

The separation of cells of each line into two subpopulations characterized by different levels of integrin receptor expression was observed. In each case, a minor subpopulation of the cells was identified, where the content of integrin receptors on the cells surface was 10 times higher than in the major population (Fig. 2, 3). It should also be noted that the expression level of recombinant protein was almost the same in both subpopulations.

So, for the fibronectin receptor (integrin $\alpha 5 \beta 1$ ) the minor subpopulation (P3) includes approximately $10 \%$ of cells (NOT (P3). P3 populations were different in median of fluorescence intensity among different cell lines and the difference reached 2.5 times (Fig. 2). However, despite the differences in the content of integrin receptors in cells from the $\mathrm{P} 3$ population of the HT-29_TR-, HT-29_TR4 and HT-29_TR12 lines, their adhesion to fibronectin was almost the same. Moreover, HT-29 TR20 cells which had the lowest expression level of $\alpha 5 \beta 1$ integrin in the $\mathrm{P} 3$ population, had the strongest adhesion to fibronectin, five times stronger than the other cell lines. Thus, neither the size of the cell population with $\alpha 5 \beta 1$ integrin overexpression, nor the expres- sion level of the integrin receptors in this population or in the total population reflects the dynamics of changes in the adhesion ability of cells of stable lines to fibronectin.

Similar results were obtained when studying the content of $\alpha v \beta 3$ integrin on the cell surface. There was no significant difference in the expression levels between lines in both the major and minor populations (Fig. 3). It should be noted that the largest size of the $\mathrm{P} 3$ subpopulation was observed in HT-29_TR- cells. However, a comparison of the number of integrin receptors on the surface of cell from different populations allowed us to conclude that there were no significant differences within each population. Thus, the difference in cell adhesion to fibronectin and vitronectin could not be accounted for by the differences in the content of fibronectin and vitronectin-recognizing receptors.

\section{The distribution of mucin in the area of cell adhesion varies with the length of its extracellular region}

Using a confocal microscope, we obtained a series of optical sections of cells expressing fusion proteins. We observed a uniform distribution of EGFP fluorescence in the adhesion region (the "lower" cell membrane attached to the glass) in HT_TR-cells (Fig. 4), indicating that the recombinant protein TR- did not participate in adhesion. Given the fact that TRlacks almost all functional domains of MUC1, this polypeptide has no regions capable of participating in adhesion and represents just an EGFP anchored in the membrane. The distribution of fluorescence in HT-29 TR1 cells was similar (Fig. 4). The TR1 protein contains only one tandem repeat and, probably, its ex- 


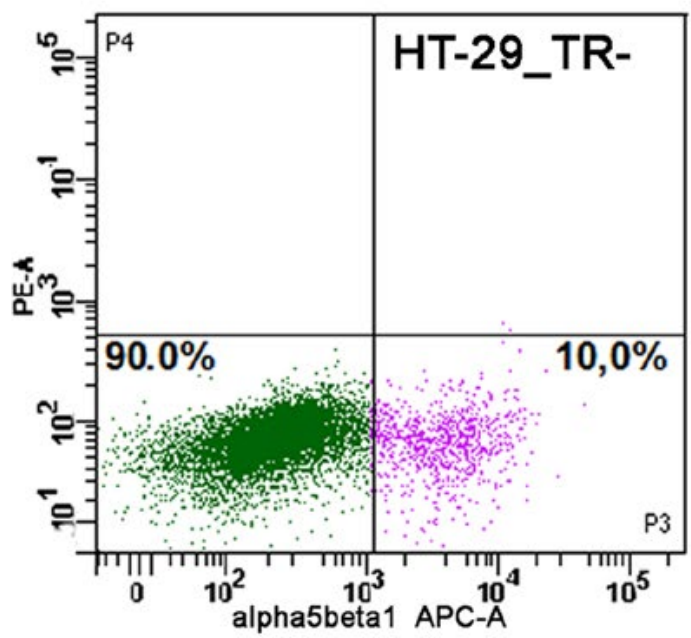

\begin{tabular}{|lrrrr|}
\hline Tube Name: & \multicolumn{2}{c|}{ TR-_alpha5_beta1 } & \\
& & & \multicolumn{2}{c}{ FITC-A alpha5... } \\
Population & \#Events & \%Parent & Median & Median \\
\hline$\square$ P2 & 9,575 & 70.9 & 629 & 237 \\
$\square$ P3 & 958 & 10.0 & 550 & 3,934 \\
$\square$ NOT(P3) & 8,617 & 90.0 & 638 & 215 \\
\hline
\end{tabular}

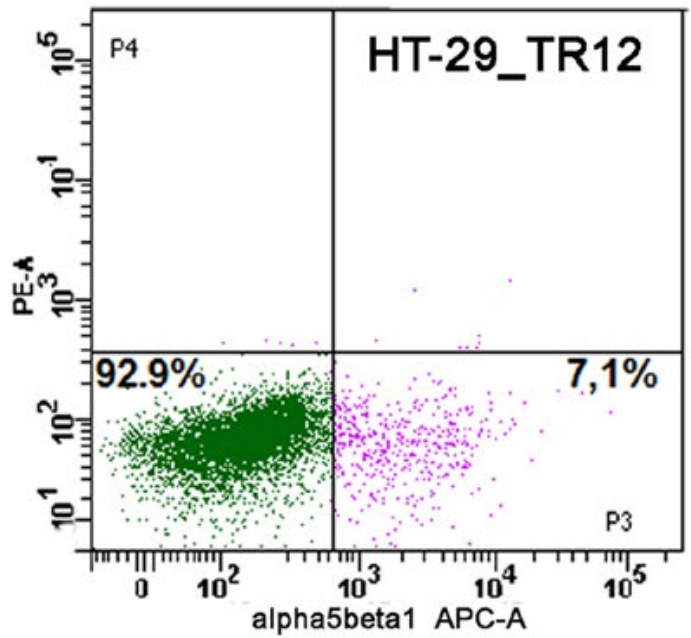

\begin{tabular}{|lrrrr|}
\hline Tube Name: & \multicolumn{4}{c|}{ TR12_alpha5_beta1 } \\
& \multicolumn{4}{c}{ FITC-A alpha5... } \\
Population & \#Events & \%Parent & Median & Median \\
\hline$\square$ P2 & 7,904 & 64.4 & 2,461 & 172 \\
$\square$ P3 & 561 & 7.1 & 2,243 & 1,716 \\
$\square$ NOT(P3) & 7,343 & 92.9 & 2,476 & 161 \\
\hline
\end{tabular}

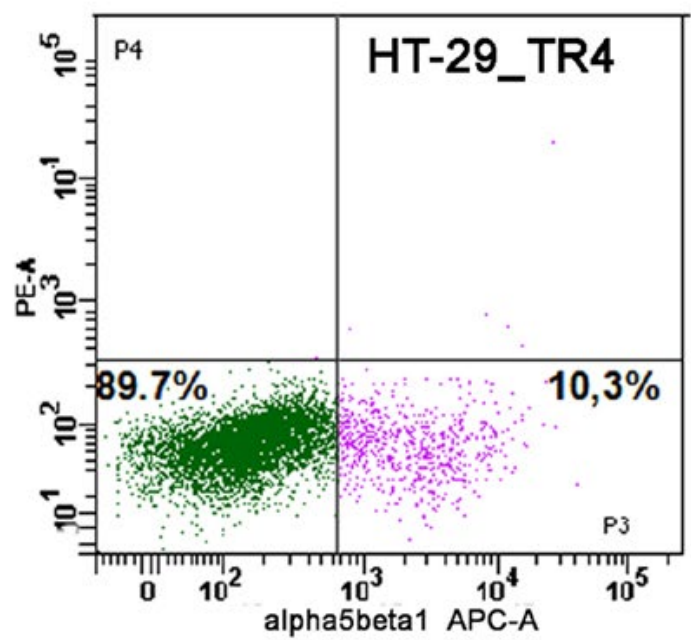

\begin{tabular}{lrrrr|} 
Tube Name: & \multicolumn{2}{c|}{ TR4_alpha5_beta1 } \\
& & \multicolumn{3}{c}{ FITC-A alpha5... } \\
Population & \#Events & \%Parent & Median & Median \\
\hline$\square$ P2 & 7.419 & 69.4 & 3,303 & 181 \\
$\square$ P3 & 765 & 10.3 & 2,961 & 2,044 \\
$\square$ NOT(P3) & 6,654 & 89.7 & 3,339 & 164 \\
\hline
\end{tabular}

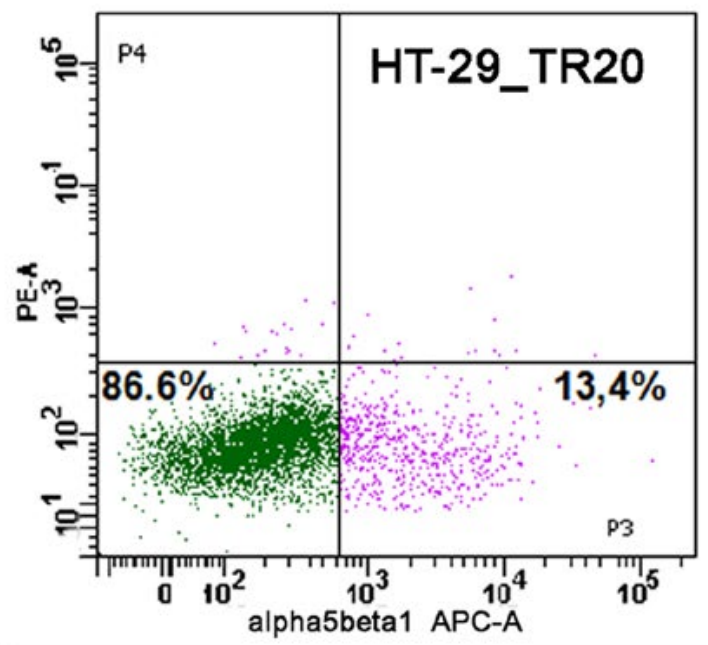

\begin{tabular}{|lrrrr|}
\hline Tube Name: & \multicolumn{3}{c|}{ TR20_alpha5_beta1 } \\
& & \multicolumn{3}{c|}{ FITC-A alpha5... } \\
Population & \#Events & \%Parent & Median & Median \\
\hline$\square$ P2 & 5,452 & 65.5 & 668 & 214 \\
\hline P3 & 728 & 13.4 & 569 & 1,614 \\
$\square$ NOT(P3) & 4.724 & 86.6 & 682 & 186 \\
\hline
\end{tabular}

Fig. 2. FACS analysis of $\alpha 5 \beta 1$ integrin expression on the surface of stable cell lines. 


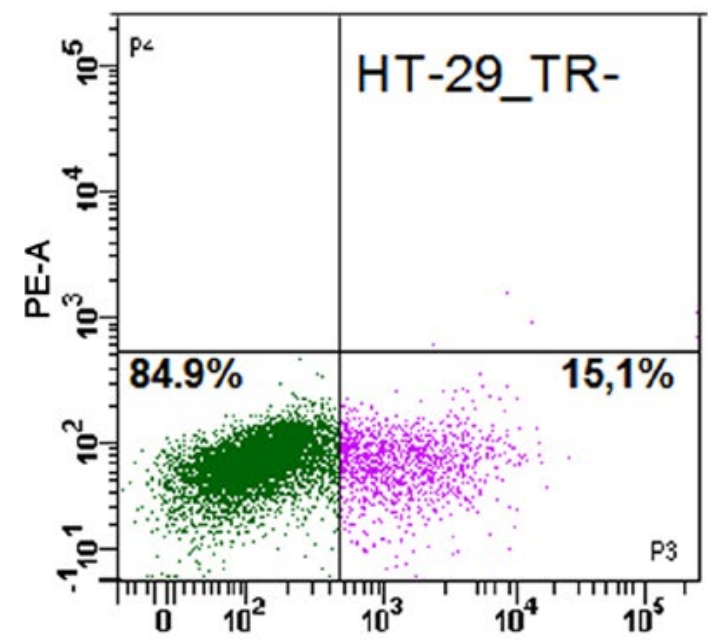

\begin{tabular}{|lrrrr|}
\hline Tube Name: & \multicolumn{4}{c|}{ TR-_alphav_beta3 } \\
Population & \#Events & \%Parent & Median & Median \\
\hline$\square$ P2 & 8,804 & 72.1 & 624 & 145 \\
\hline P3 & 1,327 & 15.1 & 556 & 1,256 \\
$\square$ NOT(P3) & 7,477 & 84.9 & 633 & 126 \\
\hline
\end{tabular}

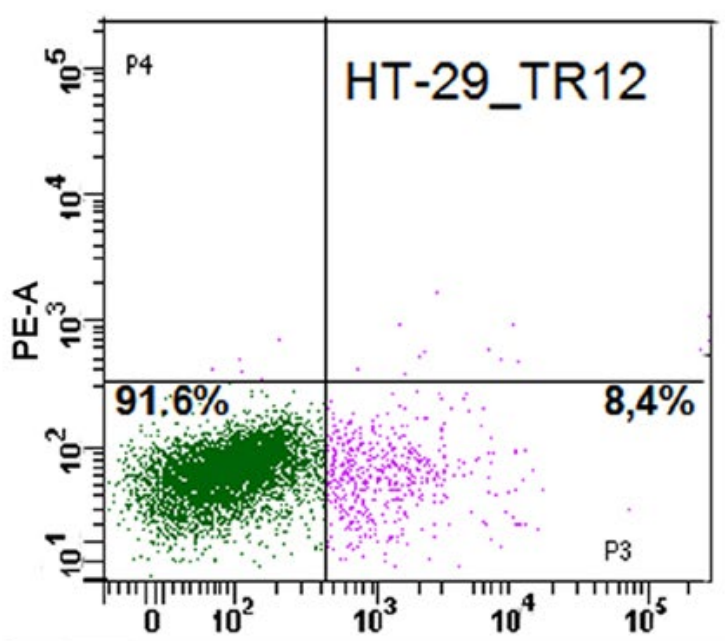

\begin{tabular}{|lrrrr|}
\hline Tube Name: & \multicolumn{4}{c|}{ TR12_alphav_beta3 } \\
Population & \#Events & \%Parent & Median & Median \\
\hline$\square$ P2 & 7,445 & 65.4 & 2,519 & 102 \\
\hline P3 & 627 & 8.4 & 2,170 & 1,028 \\
$\square$ NOT(P3) & 6,818 & 91.6 & 2,549 & 94 \\
\hline
\end{tabular}

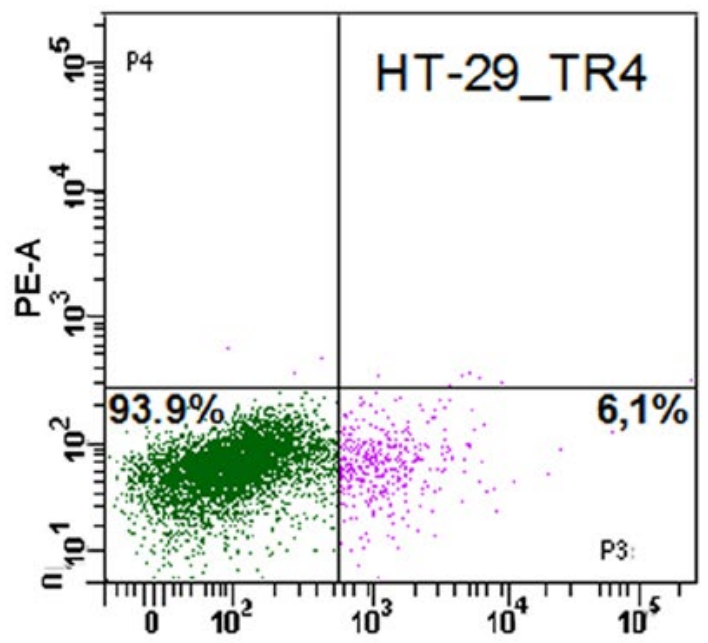

\begin{tabular}{|lrrrr|}
\hline Tube Name: & \multicolumn{4}{c|}{ TR4_alphav_beta3 } \\
Population & \#Events & \%Parent & Median & Median \\
\hline$\square$ P2 & 7,468 & 69.5 & 3,308 & 109 \\
\hline P3 & 454 & 6.1 & 2,911 & 1,125 \\
\hline NOT(P3) & 7,014 & 93.9 & 3,328 & 104 \\
\hline
\end{tabular}

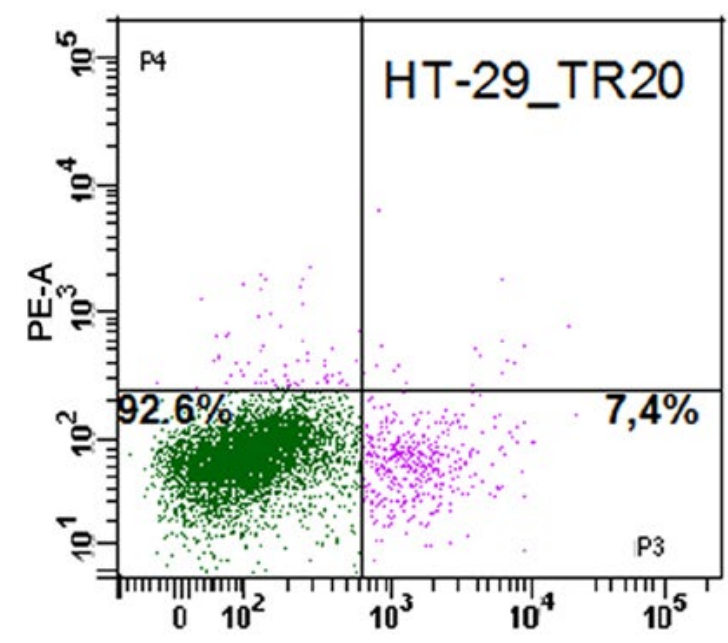

\begin{tabular}{|lrrrr|}
\hline Tube Name: & \multicolumn{4}{c|}{ TR20_alphav_beta3 } \\
Population & \#Events & \%Parent & Median & Median \\
\hline$\square$ P2 & 6,929 & 71.7 & 677 & 114 \\
\hline P3 & 512 & 7.4 & 613 & 1,440 \\
$\square$ NOT(P3) & 6,417 & 92.6 & 682 & 107 \\
\hline
\end{tabular}

Fig. 3. FACS analysis of avb3 integrin expression on the surface of stable cell lines. 

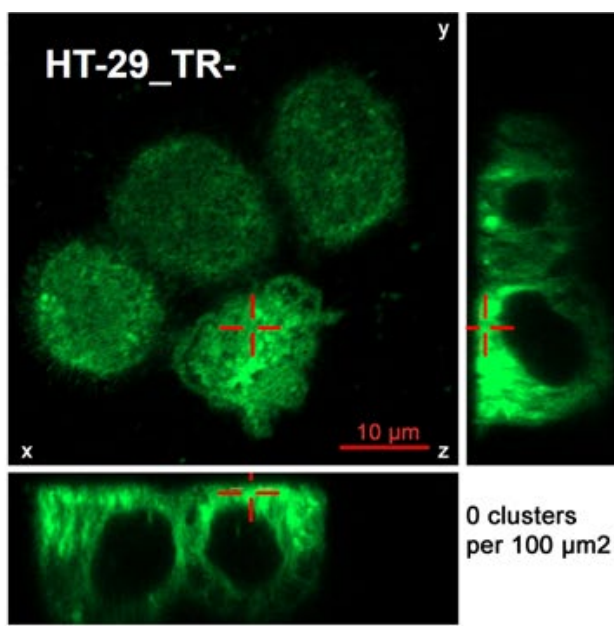

0 clusters per $100 \mu \mathrm{m} 2$
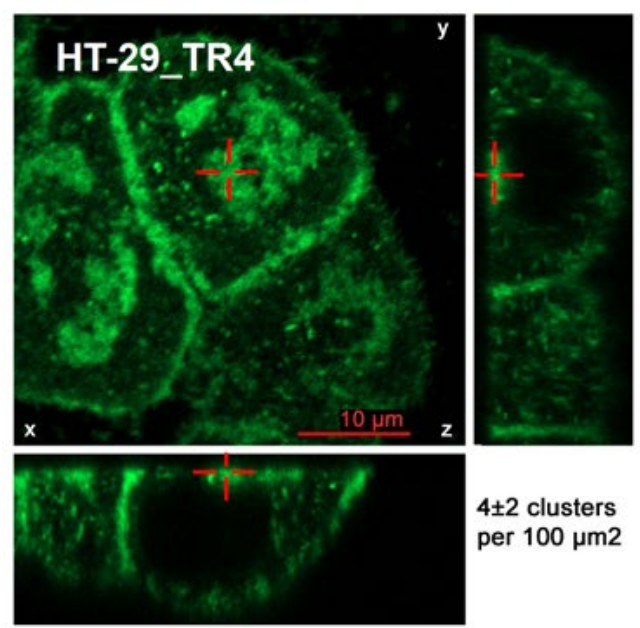

$4 \pm 2$ clusters per $100 \mu \mathrm{m} 2$
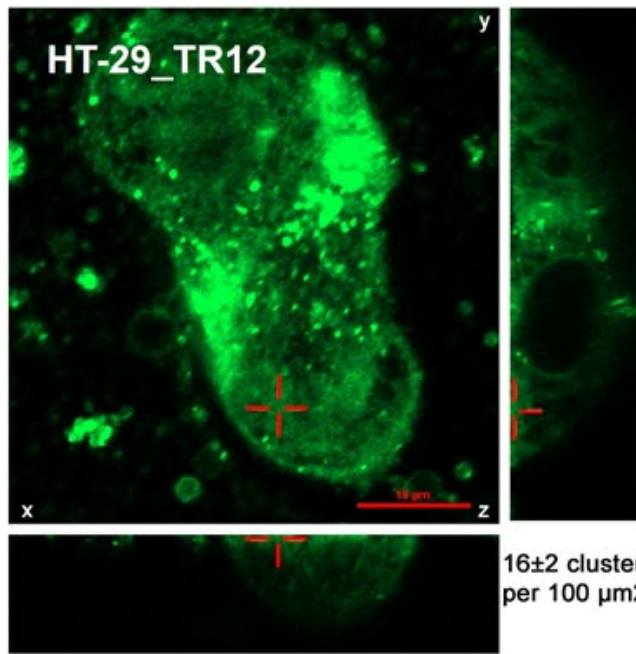

$16 \pm 2$ clusters per $100 \mu \mathrm{m} 2$
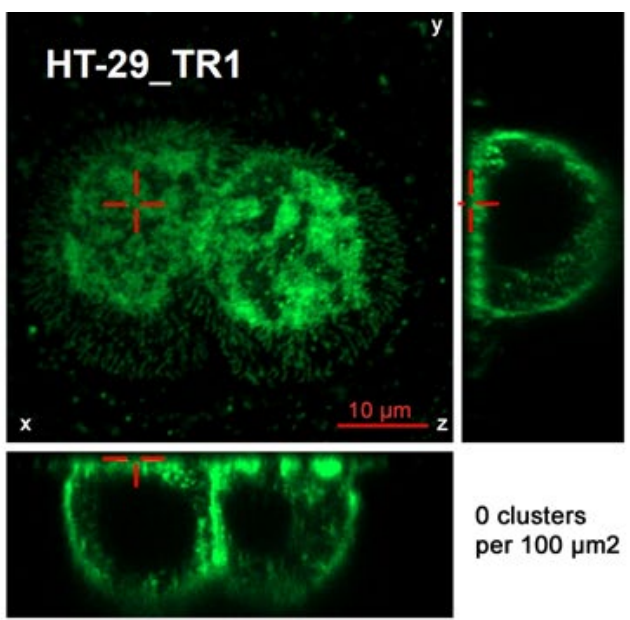

0 clusters per $100 \mu \mathrm{m} 2$
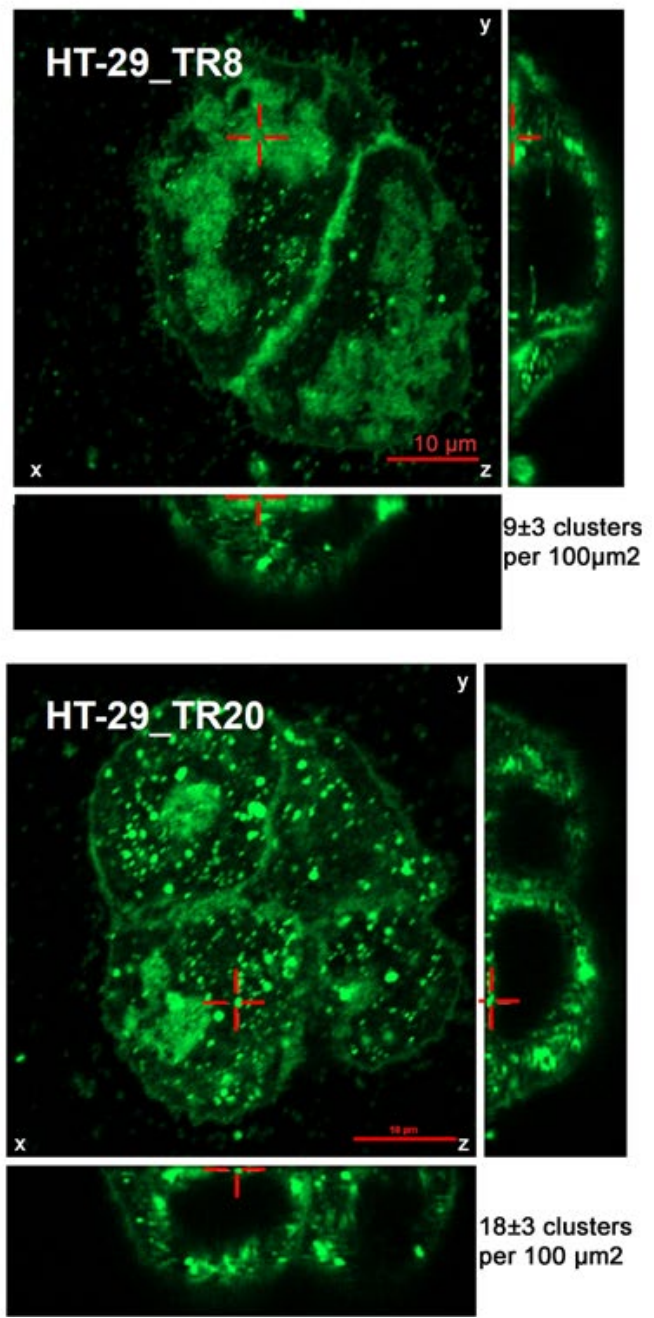

Fig. 4. EGFP fluorescence in the areas of attachment of stably transfected HT-29 cells to glass. The bottom and side panels of each image demonstrate the optical section of the three-dimensional image in $\mathrm{xz}$ and yz planes, respectively. A number of clusters per $100 \mu \mathrm{m}^{2}$ is shown in the lower right corner of each image. Data are expressed as mean (expressed as cell number) $\pm \mathrm{SD}$. At least 10 fields were analyzed for every cell line. Scale bar $=10 \mathrm{mi}-$ crometers. 
tracellular domain is too short to exert any effect on cell adhesion and form clusters. This is also confirmed by the analysis of vitronectin and fibronectin binding: the adhesion of HT29 TR 1 cells is even stronger than in HT29 TR- cells.

Starting with four tandem repeats, the fluorescence clusters become observable on the lower membrane, being the most notable in cells expressing a protein with 20 tandem repeats. The comparison of the number of MUC1 clusters per square unit between cell lines identified an increase in fluorescence discreetness with an increasing number of tandem repeats in the recombinant proteins (Fig. 4, lower right corner of each image). In the case of TR4, TR8 and TR12 proteins such clustering is rather sporadic: the protein is evenly distributed on the cell membrane, although there are large areas almost completely devoid of EGFP fluorescence. Possibly the size of the extracellular region is not sufficient to indirectly activate integrin receptors [27], but sufficient to hinder the interaction of integrin receptors with extracellular matrix proteins (Fig. 1). In cells expressing MUC1 glycoprotein with 20 tandem repeats, a pronounced clustering of EGFP fluorescence is noticeable. This may indicate an indirect activation of integrin receptors [27] leading to an unexpected increase in the adhesion ability to fibronectin and vitronectin (Fig. 1).

\section{The effect of mucin proteins on the in- tegrin avb3 and a5b1 clustering on the cell surface}

To investigate the effect of mucin proteins with extracellular domains of various lengths on integrin avb3 and a5b1 distribution, a series of confocal microscope images of the cells with double fluorescent label (EGFP label of the recombinant protein and Alexa647 label of the anti-integrin avb3 or anti-integrin a5b1 antibody) were analyzed. Integrin avb3 clustering did not depend on the number of tandem repeats in the MUC1 protein (Fig. 5, A). It is noteworthy that in the HT-29_TR- cells, the areas of integrin avb3 distribution overlap with the areas of MUC1 distribution, but in the HT29_TR4, HT-29_TR12 and HT-29_TR-20 cells, integrin receptors localize in the areas devoid of the recombinant proteins (the peaks of Alexa647 fluorescence do not overlap with the peaks of the EGFP fluorescence) (Fig. 5, A, left panels). On the basis of these observations and the results of cell adhesion assay (Fig. 1), we can assume that the extension of the VNTR region up to 12 tandem repeats inhibits the integrin avb3-mediated adhesion to vitronectin. Considering the direct relationship between a decrease in adhesion and an increase in the number of tandem repeats, we suppose the steric hindrance of integrin-ligand interaction. The surprising increase in the adhesion ability of HT-29_TR-20 cells in comparison with HT-29_TR-12 cells without any visible changes in the surface architecture may indicate the switching of the pathway of MUC1-mediated activation of integrin receptors using the mechanism described by Paszek et al. [27] or another unknown mechanism.

In the case of integrin a5b1, clustering depends on the number of tandem repeats in the MUC1 protein (Fig. 5, B). In the HT-29_TRcells, the molecules of integrin a $5 \mathrm{~b}$ are distributed uniformly (no peaks of Alexa647 fluorescence). In the cells bearing on their surfaces proteins with tandemly repeated sequences 
$A$
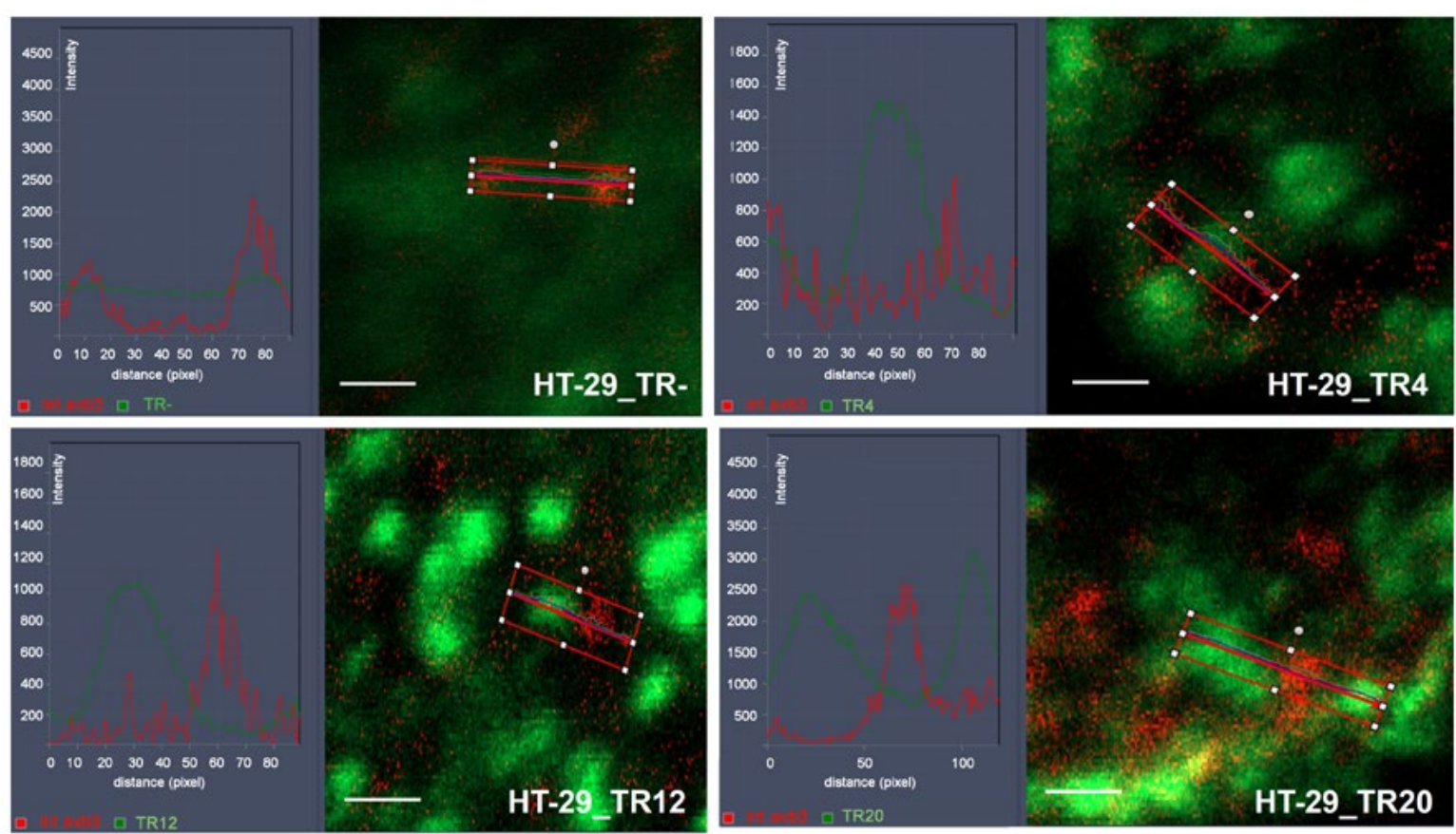

$\boldsymbol{B}$
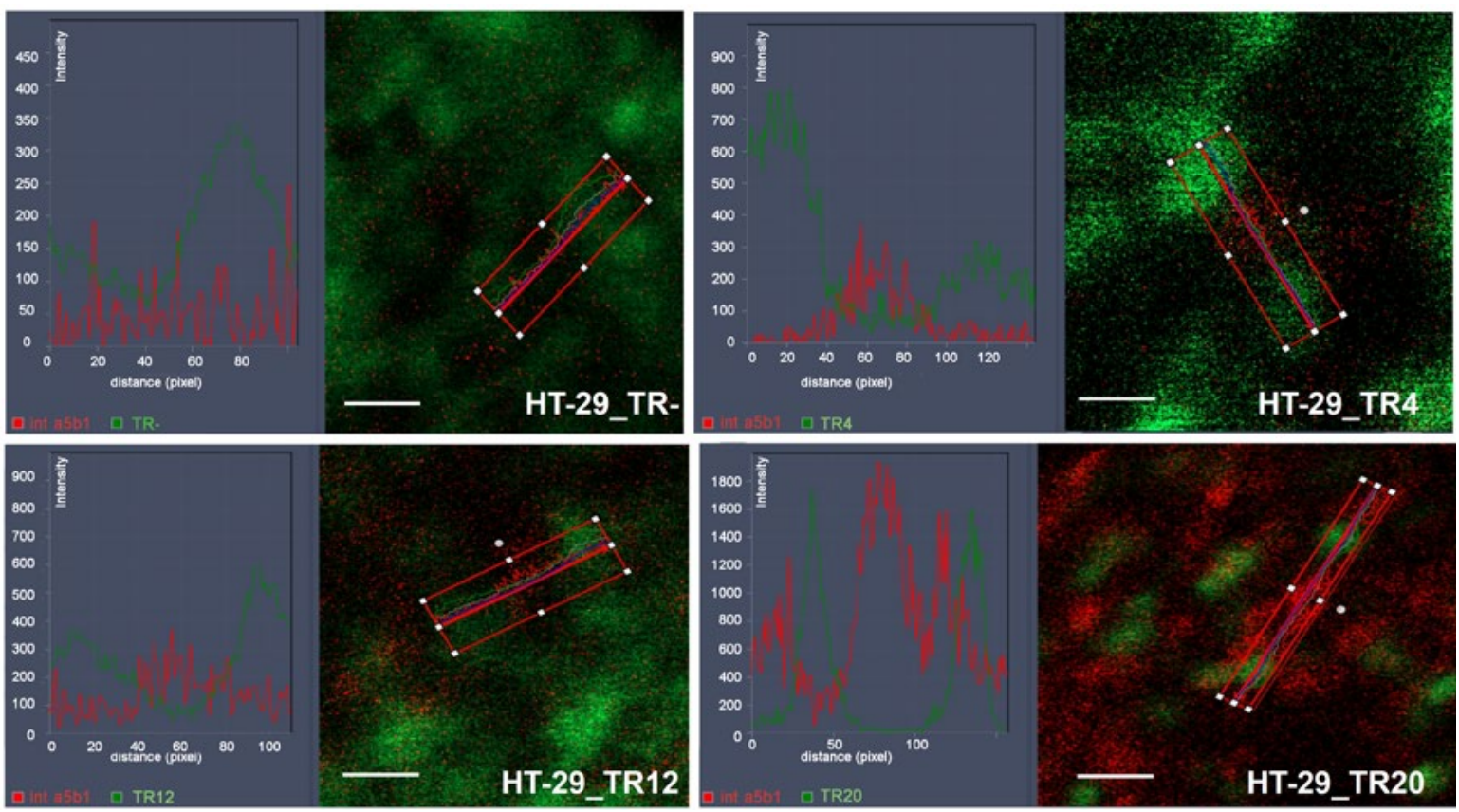

Fig. 5. Colocalization of EGFP fluorescence of recombinant proteins and Alexa647 fluorescence of anti-integrin avb3 $A-$ or anti-integrin a5b1; $B$ - antibodies in HT-29_TR-, HT-29_TR4, HT-29_TR12 and HT-29_TR20 cell lines. Scale bar 1 micrometer. Left panel of each image represents fluorescence intensity profiles for the rectangles marked by an arrow. Each image represented is one of at least 10 images, which were analyzed for every cell line. 
Short MUC1 molecules (TR- - TR12) on
the cancer cell surface

No integrin a5b1 clustering (red signal) on the surface of MIC1-expressing cells

(MUC1 - green signal)

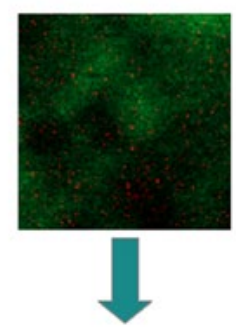

Prevalence of inactive integrins on the cell surface

weak adhesion
Full-length MUC1 molecules (TR20) on the cancer cell surface

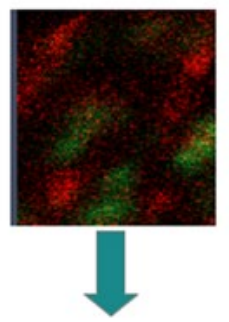

MUC1-mediated clustering of the integrin a5b1 (red signal) on the surface of MIC1-expressing cells (MUC1 - green signal)

Prevalence of active integrins on the cell surface strong adhesion Extracellular matrix

Fig. 6. Graphic representation of the cross-talk between mucin MUC1 and integrin a5b1 molecules in cell adhesion.

(HT-29_TR4, HT-29_TR12 and HT-29_TR20), the signal of Alexa647 fluorescence localizes in the areas devoid of recombinant proteins (the peaks of Alexa647 fluorescence do not overlap with the peaks of the EGFP fluorescence) (Fig. 5, B). But only in the HT-29 TR-20 cells, the clusters with a high density of receptors form on the cell surface. This observation was made by comparing the Alexa647 fluorescence signal intensity in the integrin-rich areas on the surfaces of the cells from different cell lines (Fig. 5, B, left panels). The correlation of these data with the cell adhesion (Fig. 1) suggests an activation of integrin a $5 \mathrm{~b} 1$ receptors by TR20, due to induction of the integrin clustering, followed by enhanced cell adhesion to fibronectin (Fig. 6).

\section{Conclusions}

1. The adhesion of cells overexpressing human mucin MUC1 to extracellular matrix proteins depends on the size of the tandem repeat region.
2. The increase in the number of tandem repeats up to 12 (TR12) may disrupt an interaction of integrin avb3 receptors with vitronectin (but does not interfere with integrin clustering); this is reflected in the reduction in adhesion. However, when the length of MUC1 extracellular region reaches 20 tandem repeats (TR20), MUC1 stimulates adhesion.

3. An apperance of tandem repeats on the cell surface leads to the aggregation of integrin a5b1 molecules in the areas devoid of MUC1 molecules. Integrin a5b1 molecules form clusters with the high density of the receptors on the surface of TR20-expressing cells. As a result, HT-29_TR20 cells demonstrate an increased adhesion to fibronectin in contrast to other cell lines (Fig. 6).

\section{Funding}

This work was partially supported by RFBR (grants 16-34-60233 and 19-04-00891) 


\section{REFERENCES}

1. van Zijl F, Krupitza G, Mikulits W. Initial steps of metastasis: cell invasion and endothelial transmigration. Mutat Res. 2011; 728(1-2):23-34.

2. Liotta LA. Adhere, Degrade, and Move: The ThreeStep Model of Invasion. Cancer Res. 201; 76(11):3115-7.

3. Tremblay P-L., Huot J, Auger FA. Mechanisms by which E-selectin regulates diapedesis of colon cancer cells under flow conditions. Cancer Res. 2008; 68(13):5167-76.

4. St Hill C. Interactions between endothelial selectins and cancer cells regulate metastasis. Front Biosci. 2011; 16:3233-51.

5. Wirtz D, Konstantopoulos K, Searson PC. The phy sics of cancer: the role of physical interactions and mechanical forces in metastasis. Nat Rev Cancer. 2011; 11(7):512-22.

6. Borsig L, Wong R, Hynes RO, Varki NM, Varki A. Synergistic effects of L- and P-selectin in facilitating tumor metastasis can involve non-mucin ligands and implicate leukocytes as enhancers of metastasis. Proc Natl Acad Sci U S A. 2002; 99(4):2193-8.

7. Varki NM, Varki A. Diversity in cell surface sialic acid presentations: implications for biology and disease. Lab Invest. 2007; 87(9):851-7.

8. Gehlsen KR, Davis GE, Sriramarao P. Integrin expression in human melanoma cells with differing invasive and metastatic properties. Clin Exp Metastasis. 1992; 10(2):111-20.

9. Hynes $R O$. Integrins: bidirectional, allosteric signaling machines. Cell. 2002; 110(6):673-87.

10. Fontenot J, Tjandra $N, B u$ D, Ho C, Montelaro RC, Finn OO. Biophysical characterization of one-, two-, and three-tandem repeats of human mucin (muc-1) protein core. Cancer research. 1993; 53(22):5386-94.

11. Gendler SJ, Taylor-Papadimitriou J, Duhig T, Rothbard J, Burchell J. A highly immunogenic region of a human epithelial mucin expressed by carcinomas is made up of tandem repeats. J. Biol. Chem., 1988; 263(26): 12820-3.

12. Siddiqui J, Abe M, Hayes D, Shani E, Yunis E, Kufe D. Isolation and sequencing of a cDNA coding for the human DF3 breast carcinoma-associated antigen. Proc. Natl. Acad. Sci. USA, 1988; 85(7):2320-3.

13. Zrihan-Licht S, Vos HL, Baruch A, Elroy-Stein $O$, Sagiv D, Keydar I, Hilkens J, Wreschner D. Characterization and molecular cloning of a novel MUC1 protein, devoid of tandem repeats, expressed in human breast cancer tissue. Eur. J. Biochem. 1994; 224(2):787-95.

14. Oosterkamp HM, Scheiner L, Stefanova MC, Lloyd KO, Finstad CL, Baruch A, Hartmann M, Zrihan-Licht S, Greenstein S, Burstein M, Keydar I, Weiss M, Smorodinsky N, Wreschner DH. Preferential expression of novel MUC1 tumor antigen isoforms in human epithelial tumors and their tumor-potentiating function. Int J Cancer. 1997; 71(5):741-9.

15. Carvalho F, Seruca R, David L, Amorim A, Seixas M, Bennet E, Clausen H, Sobrinho-Simoes M. MUC1 gene polymorphism and gastric cancer an epidemiological study. Glycon. J. 1997; 14(1):107-11.

16. Guo X, Pace RG, Stonebraker JR, Commander CW, Dang AT, Drumm ML, Harris A, Zou F, Swallow DM, Wright FA, O'Neal WK, Knowles MR. Mucin variable number tandem repeat polymorphisms and severity of cystic fibrosis lung disease: significant association with MUC5AC. PLoS One. 2011; 6(10):e25452.

17. Wesseling $J$, van der Valk $S W$, Vos HL, Sonnenberg A, Hilkens $J$. Episialin (MUC1) overexpression inhibits integrin-mediated cell adhesion to extracellular matrix components. J Cell Biol. 1995; 129(1):255-65.

18. McAuley JL, Linden SK, Png CW, King RM, Pennington HL, Gendler SJ, Florin TH, Hill JR, Korolik $V$, McGuckin MA. MUC1 cell surface mucin is a critical element of the mucosal barrier to infection. $J$ Clin Invest. $2007 ;$ 117(8):2313-24

19. Ligtenberg MJ, Buijs F, Vos HL, Hilkens J. Suppression of Cellular Aggregation by High Levels of Episialin. Cancer Res. 1992; 52(8):2318-24

20. Wesseling $J$, van der Valk $S W$, Hilkens $J$. A mechanism for inhibition of E-cadherin-mediated cell-cell adhesion by the membrane-associated mucin episialin/MUC1. Mol Biol Cell. 1996; 7(4):565-77. 
The length of mucin MUC1 extracellular domain affects integrin-mediated cell adhesion to fibronectin and vitronectin

21. Feng H, Ghazizadeh M, Konishi H, Araki T. Expression of MUC1 and MUC2 mucin gene products in human ovarian carcinomas. Jpn J Clin Oncol. 2002; 32(12):525-9.

22. Zhao Q, Barclay M, Hilkens J, Guo X, Barrow H, Rhodes $J M, Y u L G$. Interaction between circulating galectin-3 and cancer-associated MUC1 enhances tumour cell homotypic aggregation and prevents anoikis. Mol Cancer. 2010; 9:154.

23. Rahn JJ, Shen Q, Mah BK, Hugh JC. MUC1 initiates a calcium signal after ligation by intercellular adhesion molecule-1. J Biol Chem. 2004; 279(28):29386-90.

24. Mori Y, Akita K, Yashiro M, Sawada T, Hirakawa K, Murata T, Nakada H. Binding of galectin-3, a $\beta$-galactoside-binding lectin, to MUC1 protein enhances phosphorylation of extracellular signal-regulated kinase 1/2 (ERK1/2) and Akt, promoting tumor cell malignancy. $J$ Biol Chem. 2015; 290(43):26125-40.

25. Geng Y, Yeh K, Takatani T, King MR. Three to tango: MUC1 as a ligand for both E-selectin and ICAM-1 in the breast cancer metastatic cascade. Front Oncol. 2012; 2:76.

26. Rahn JJ, Chow JW, Horne GJ, Mah BK, Emerman JT, Hoffman P, Hugh JC. MUC1 mediates transendothelial migration in vitro by ligating endothelial cell ICAM-1. Clin Exp Metastasis. 2005; 22(6):475-83.

27. Paszek MJ, DuFort CC, Rossier O, Bainer R, Mouw JK, Godula K, Hudak JE, Lakins JN, Wijekoon AC, Cassereau L, Rubashkin MG, Magbanua MJ, Thorn KS, Davidson MW, Rugo HS, Park JW, Hammer DA, Giannone G, Bertozzi CR, Weaver $V M$. The cancer glycocalyx mechanically primes integrin-mediated growth and survival. $\mathrm{Na}$ ture. 2014; 511(7509):319-25.

28. Syrkina M, Viushkov V, Potashnikova D, Veiko V, Vassetzky Y, Rubtsov M. From an increase in the number of tandem repeats through the decrease of sialylation to the downregulation of MUC1 expression level. J Cell Biochem. 2019; 120(3): 4472-84.

29. Syrkina MS, Maslakova AA, Potashnikova DM, Veiko VP, Vassetzky YS, Rubtsov MA. Dual Role of the extracellular domain of human mucin MUC1 in metastasis. J Cell Biochem. 2017; 118(11):4002-11.

\section{Участь муцину MUC1 у інтегрін-}

опосередкованій адгезії клітин до фібронектину та вітронектину залежить від довжини його позаклітинного домену

М. С. Сиркіна, Д. М. Поташнікова, М. А. Рубцов

Мета. Встановити, чи існує відмінність у адгезії до білків позаклітинного матриксу у клітин стабільних ліній, що експресують рекомбінантні злиті білки, що містять в позаклітинному домені різну кількість тандемних повторів з області VNTR муцина MUC1 людини. Методи. Аналіз клітинної адгезії, проточна цитометрії, конфокальна флуоресцентна мікроскопія. Результати. При збільшенні числа тандемних повторів в позаклітинній області муцина MUC1 людини спочатку рівномірний розподіл рекомбінантного білка в області контакту клітини зі склом змінюється на дискретний, а потім відбувається формування компактних кластерів. Адгезія клітин до вітронектину і фібронектину не залежить від кількості інтегрінових рецепторів на клітинній поверхні, зменшуючись в ряду: НT-29_TR4 $\rightarrow$ HT-29_TR12. У клітин НT-29_TR20 спостерігається збільшення адгезії до даних білків позаклітинного матриксу. Інтегрин avb3 (рецептор вітронектину) кластеризуються в клітинах всіх проаналізованих ліній, в той час як интегрин a5b1 (рецептор фібронектину) утворює компактні кластери тільки на поверхні клітин HT-29_TR20. Обидва інтегріна розподілені в областях, позбавлених молекул MUC1 на поверхні клітин HT-29_TR4, HT-29_TR12 і НT-29_TR20, а розподіл даних інтегрінов на поверхні клітин HT-29_TR- не залежить від локалізації рекомбінантного білку. Висновки. Збільшення числа тандемних повторів в позаклітинній області муцина MUC1 від 12 до 20 призводить до помітного ослаблення антагонізму муцину MUC1 по відношенню до інтегринів avb3 при адгезії клітин до вітронектину і появи синергізму по відношенню до інтегринів а5b1 при адгезії клітин до фібронектину

Ключ ов і сл ов а: MUC1, інтегріни, avb3, a5b1, адгезія , кластерізація 


\section{Участие муцина MUC1 в интегрин- опосредованной адгезии клеток к фибронектину и витронектину зависит от длины его внеклеточного домена}

М. С. Сыркина, Д. М. Поташникова, М. А. Рубцов

Цель. Установить, существует ли отличие в адгезии к белкам внеклеточного матрикса у клеток стабильных линий, экспрессирующих рекомбинантные слитые белки, содержащие в внеклеточном домене различное количество тандемных повторов из области VNTR муцина MUC1 человека. Методы. Анализ клеточной адгезии, проточная цитометрия, конфокальная флуоресцентная микроскопия. Результаты. При увеличении числа тандемных повторов в внеклеточной области муцина MUC1 человека сначала равномерное распределение рекомбинантного белка в области контакта клетки со стеклом изменяется на дискретное, а затем происходит формирование компактных кластеров. Адгезия клеток к витронектину и фибронектину не зависит от количества интегриновых рецепторов на клеточной поверхности, уменьшаясь в ряду: HT-29_TR4 $\rightarrow$ HT-29_TR12. У клеток HT-29_TR20 наблюдается увеличение адгезии к данным белкам внеклеточного матрикса. Интегрин avb3 (рецептор витронектина) кластеризуется в клетках всех проанализированных линий, в то время как интегрин a5b1 (рецептор фибронектина) образует компактные кластеры только на поверхности клеток НT-29_TR20. Оба интегрина распределены в областях, лишенных молекул MUC1 на поверхности клеток НT-29_TR4, НT29_TR12 и HT-29_TR20, а распределение данных интегринов на поверхности клеток HT-29_TR- не зависит от локализации рекомбинантного белка. Выводы. Увеличение числа тандемных повторов в экстрацеллюлярной области муцина MUC1 от 12 до 20 приводит к заметному ослаблению антагонизма муцина MUC1 по отношению к интегрину avb3 при адгезии клеток к витронектину и появлению синергизма по отношению к интегрину а5b1 при адгезии клеток к фибронектину.

Ключевые слова: MUC1, интергины, avb3, a5b1, адгезия, кластеризация

Received 10.02.2019 